\title{
MEWASPADAI KEKERASAN SIMBOLIK DALAM RELASI ORANG TUA DAN ANAK
}

\author{
Ulya \\ Sekolah Tinggi Agama Islam Negeri Kudus \\ Email:ulya.kamera@gmail.com
}

\section{ABSTRAK}

Artikel ini bertujuan menelusuri adanya kekerasan simbolik dalam pendidikan anak oleh orang tua dalam keluarga. Kekerasan simbolik merupakan kekerasan yang sifatnya laten, tidak disadari, baik oleh pelaku maupun korbannya termasuk dalam relasi orang tua dan anak. Melalui kajian berpendekatan kritis dan menggunakan teori kritis kekerasan simbolik Pierre Bourdieu ditemukan bahwa dalam mendidik anak-anak, seringkali orang tua menggiring anak menuju ruang tunggal berpendapat, bersikap, atau berperilaku tertentu tanpa alternatif. Anak dipaksa cenderung mengikuti tuturan orang tua dengan alasan ketaatan dan takut dicap durhaka. Bentuk relasi ini dipandang wajar sebagai hal yang seharusnya terjadi antara anak dan orang tua. Relasi ini perlu diwaspadai karena melekat kekerasan simbolik. Dan kekerasan simbolik ini menjadi pintu gerbang yang melahirkan kekerasan-kekerasan lain yang sifatnya lebih nyata

Kata Kunci: Orang tua, kekerasan, simbolik, pola asuh 
This article explore the symbolic violence in the education of children by parents in their family. Symbolic violence is a latent violence, unconscious, which is not perceived by the perpetrators and the victims. By using critical approach and critical theory of Bourdieu's symbolic violence, this article find that the parents usually let their children towards a single space to think, to act or behave in certain ways without opportunity to speak or choose another options. Children tend to follow their parents by reason of obedience and fear of being labeled as insubordinate one. In this kind of relationship, both parents and children do not feel a circle of violence. Both looked at the relationship as -taken for granted-thing and should be like that. Symbolic violence should be woried about as a gateway that spawns other kinds of more real violence.

Keywords: parents, simbolic violence, parenting.

\section{A. Pendahuluan}

Kasus kekerasan yang menimpa anak-anak semakin hari semakin mengkhawatirkan, baik dari sisi jumlahnya yang terus meningkat maupun dari sisi jenisnya yang semakin beragam, mulai pembunuhan, pencabulan, pemerkosaan, penelantaran, penculikan, pemukulan, penyekapan, sampai yang hanya sekedar membuat mereka gelisah. Kekerasan memang meninggalkan bekas luka yang mengerikan, menyakitkan, bahkan mematikan. Kekerasan pada anak-anak, pelaku biasanya bukanlah orang yang tak dikenal oleh mereka. Seringkali pelakunya justru orang-orang yang sudah dikenal dekat, seperti: guru, saudara, teman, tetangga, orang tua tiri, bahkan orang tua kandung sendiri.

Fenomena kekerasan yang dimaksud di atas adalah kekerasan yang nyata, yang mudah dikenali dan mudah diamati sehingga penyelesaiannyapun terasa lebih mudah pembuktiannya. Di samping ada kekerasan yang bersifat nyata sebagaimana tersebut, ada pula 
kekerasan yang laten, yang pelakunya tidak merasa, korbannya juga tidak menyadari, dan orang lainpun tidak mengenali. Kekerasan ini disebut dengan kekerasan simbolik.

Kekerasan simbolik telah mewarnai di segala relung-relung kehidupan. Setiap ada relasi sosial yang tak seimbang atau tak setara bisa dipastikan di situlah tempat berlangsungnya kekerasan simbolik, seperti: dalam kehidupan politik, sosial, ekonomi, kesehatan, pendidikan, bahkan dalam ranah praktik keberagamaan, dan dalam keluarga.

Bagi anak-anak, keluarga seharusnya adalah tempat yang paling nyaman dan aman bagi mereka, ada orang tua yang melindungi, ada saudara-saudara yang saling menyayangi. Keluarga seperti ini akan membantu mereka menjadi manusia yang sebenarbenarnya, yakni mandiri dan bertanggungjawab. Dengan segala potensi yang dimiliki, mereka akan bisa mengembangkan daya kreatifnya dan mereka akan menjadi diri sendiri; namun dalam kenyataannya banyak keluarga yang tak bisa memerankan hal ini. Terhadap anak, orang tua banyak sekali menuntut anak-anaknya, banyak mengumbar kata tidak boleh, tidak baik, tidak benar, dan seterusnya, belum lagi ditambah dengan kebiasaan saudara yang suka menakut-nakuti atau mengancam. Semua dilakukan dengan alasan menjaga, menyayangi, bahkan mendidik. Anak diarahkan dan digiring untuk mematuhinya tanpa ada pilihan lainnya. Jika anak membantahnya atau menolaknya maka anak akan menerima hukuman dengan dalih pendisiplinan dan menaati aturan, kemudian anak tidak diberi uang saku, tidak boleh bermain dengan temannya, dibentak, sampai kadang-kadang sampai dipukul. Kondisi semacam inilah salah satu bukti beroperasinya kekerasan simbolik yang sering terjadi dalam keluarga, terutama dalam relasi antara orang tua dan anak. Kekerasan simbolik harus diwaspadai karena beresiko tinggi melahirkan kekerasan yang nyata, baik kekerasan ekonomi, kekerasan sosial, kekerasan psikis, bahkan kekerasan fisik .

Artikel ini mengulas dengan memulai menjelaskan tentang 
apa pengertian kekerasan simbolik, bagaimana cara beroperasinya, bagaimana cara mengenalinya, apa akibat-akibatnya, dan bagaimana meminimalisasinya.

Dalam pembahasan artikel ini, penulis menggunakan pendekatan kritis dengan meminjam teori sosial kritis Pierre Bourdieu tentang kekerasan simbolik. Pendekatan dan teori ini memang memiliki karakteristik khas yang bertujuan untuk mempertanyakan kembali kondisi yang selama ini justru dianggap sudah mapan. Pendekatan dan teori kritis ini menelisik dan mengungkap hal-hal yang sebenarnya ada dan terjadi di sekitar kita, namun seringkali kita tak menyadari adanya.

\section{B. Pembahasan}

\section{Kekerasan Simbolik}

Membincang persoalan kekerasan pada umumnya berkaitan dengan sikap kesewenang-wenangan yang nyata dari pihak dominan atas pihak sub-dominan. Biasanya kekerasan bersifat destruktif, merusak terhadap segala bentuk kemapanan, baik kemapanan cara berperilaku, cara bersikap, maupun cara berpikir seseorang. Efeknya sangat jelas, bisa meninggalkan bekas luka serius pada fisik, merasa gelisah, tertekan, bahkan sampai traumatis.

Kekerasan yang menjadi bahan kajian dalam tulisan ini bukan kekerasan dengan ciri-ciri di atas. Realitas kekerasan ini sulit dideteksi. Tidak ada unsur destruksi di dalamnya. Kekerasan ini beroperasi di bawah ketidaksadaran pelaku maupun korbannya sehingga bersifat nirsadar dan laten. Oleh Pierre Bourdieu (1930-2002), seorang sosiolog, juga filosof kritis dari Perancis, yang demikian itu dinamai dengan kekerasan simbolik.

Dinamai kekerasan simbolik karena karena dampak yang biasa dilihat dalam kekerasan fisik tidak kelihatan. Prinsip simbolis ini diketahui dan diterima baik oleh pihak dominan yang menguasai dan pihak subdominan yang dikuasai. Prinsip ini menyerang dan 
menentukan cara berpikir, melihat, merasakan, dan bertindak individu (Haryatmoko, 2007: 136-137).

Oleh Bourdieu, kekerasan simbolik ini muncul dari adanya struktur kelas dalam masyarakat. Adanya struktur kelas dalam masyarakat adalah sebagai akibat langsung dari adanya perbedaan, pemisahan, ketidaksamaan, ketidaksetaraan atau ketidakseimbangan atau distingsi (distinction). (William E. Deal and Timothy K. Beal: 2004: 62,64). Adanya distingsi dalam masyarakat disebabkan faktor kepemilikan modal (capital). Kepemilikan modal oleh pihak tertentu mengakibatkan ada pihak yang dianggap lebih unggul di satu sisil dan ada pihak yang terpinggirkan pada sisi yang lain.

Bourdieu memetakan jenis modal menjadi 4 (empat), yaitu: modal ekonomi atau finansial, modal budaya, modal sosial, dan modal simbolik. Adapun penjelasan masing-masing sebagai berikut:

a. Modal ekonomi atau finansial adalah kepemilikan sarana produksi dan atau sarana finansial.

b. Modal budaya, meliputi kepemilikan ijazah, pengetahuan, kode budaya, cara berbicara, kemampuan menulis, cara pembawaan, cara bergaul, yang berperan dalam penentuan kedudukan sosial. Kapital budaya ini terbagi dalam 3 (tiga) bentuk, yaitu:

1). Yang terintegrasikan ke dalam diri yaitu pengetahuan yang diperoleh selama studi dan yang disampaikan melalui lingkungan sosialnya

sehingga membentuk disposisi yang tahan lama,

2). Kapital budaya obyektif yang meliputi seluruh kekayaan budaya (buku, karya-karya seni), dan

3). Kapital budaya yang terinstitusionalisir, bisa berupa: gelar pendidikan yang dilegalkan oleh institusi, menjadi anggota asosiasi ilmuwan prestisius.

c. Modal sosial berupa kemampuan bekerjasama karena budaya kerjasama melahirkan kepercayaan. Semua dimensi sosial, organisasi, institusi, keluarga, merupakan tempat tumbuhnya 
kapital sosial.

d. Modal simbolik bisa berupa jabatan, mobil mewah, gelar, status tinggi, nama besar keluarga (William E. Deal and Timothy K. Beal, 2004: 64, Haryatmoko, 2010: 17-18).

Dengan demikian maka kekerasan simbolik ada di mana mana, dalam latar yang nyata sampai pada latar yang tersembunyi sekalipun, di dunia ekonomi dalam hubungan antara pemilik modal atau pengusaha dan buruh; dalam interaksi sosial, antara laki-laki dan perempuan; di panggung politik, antara pemerintah dengan rakyatnya; dalam praktik pendidikan, antara guru dan siswa; pada lingkaran kesehatan, antara dokter dan pasien; juga tak terkecuali dalam praktik keberagamaan, antara ulama dan masyarakat awam; dan dalam keluarga seperti antara orang tua dan anak, dan lain-lain, juga di seluruh tingkatan paedagogik dimanapun diselenggarakan bahwa di situlah juga melekat kekerasan simbolik, yakni selama ada pihak dominan yang berdaya upaya menentukan sistem nilai tertentu atas pihak subdominan lainnya.

Kekerasan simbolik yang berada dalam setiap adanya relasi sosial yang tak setara dapat ditengarai dengan adanya dominasi simbolik. Pada umumnya dominasi simbolik merepresentasikan dirinya dalam bentuk: 1). Pelaku mengkategorisasikan, membagi, dan memanipulasi korbannya dalam kelompok atau komunitas tertentu. Contoh: pelaku mengatakan jika ada orang muslim yang tidak melakukan salat maka dia kafir atau jika ada anak yang mengabaikan perintah ibunya maka dia termasuk orang yang durhaka, dan lainlain; 2). Pelaku mendatangi dan menilai korbannya dengan klaimklaim ilmiah. Contoh: di hadapan guru-guru, pelaku mengatakan bahwa mereka yang melakukan ujian lisan akan mendapatkan hasil yang lebih obyektif dari pada mereka yang melakukan ujian secara tertulis; di hadapan siswa-siswa, pelaku berkata bahwa kewajiban bagi siswa adalah belajar dan belajar agar lulus dalam ujian nanti ; 3). Pelaku membentuk korbannya ke dalam makna - memberi pada mereka sendiri, seperti seorang suami yang berkata kepada 
isterinya :"Kamu boleh bekerja di luar rumah asalkan anak-anak tetap terawat karena tugas seorang isteri itu adalah mendidik anakanak” (Paul Rabinow (ed.), 1984: 12).

\section{Mekanisme Kekerasan Simbolik}

Mencermati keterkaitan antara dominasi simbolik dengan kekerasan simbolik dalam contoh-contoh di atas, maka sesungguhnya munculnya kekerasan simbolik pasti melibatkan wacana. Istilah lain bahwa kekerasan simbolik beroperasi melalui kekuatan wacana dalam sebuah komunikasi dua pihak.

Wacana dalam definisi Foucault adalah segala sesuatu yang diproduksi (barangkali semua yang diproduksi) oleh kelompok tanda. Juga sebagai ketetapan formulasi, rangkaian kalimat atau proposisi. Istilah lain bahwa wacana didefinisikan sebagai sekelompok pernyataan yang berkaitan erat dengan sistem formasi tunggal (Foucault,2002:121). Sedangkan dalam bahasa Ricoeur, wacana menunjuk kepada bahasa sebagai event, yaitu bahasa yang membicarakan sesuatu, bahasa yang digunakan dalam komunikasi, baik lisan maupun tertulis (Ricoeur, 2003:217-218). Wacana semacam ini mempersyaratkan 4 (empat) hal, yaitu : ada subyek yang mengatakan, kepada siapa ditujukan, wahana atau dunia yang direpresentasikan, dan temporalitas atau konteks waktu.

Wacana memang merujuk pada bahasa tetapi tidak pada setiap bahasa yang digunakan dalam aktivitas komunikasi, tidak sekedar bahasa dalam aktivitas perbincangan sehari-hari (everyday speech act). Wacana merujuk pada aktus perbincangan yang serius (serious speech act). (Hubert L. Dreyfus dan Paul Rabinow, 1982 :48). Adapun yang dimaksud dengan aktus perbincangan yang serius (serious speech act) adalah sebuah pernyataan yang berasal dari perbincangan sehari-hari tetapi ditetapkan lewat suatu prosedur validasi yang niscaya atau ditetapkan oleh suatu komunitas ahli yang memiliki otoritas (Rudy Harisyah Alam dalam Mastuhu dan 
M. Deden Ridwan (ed.), 1998: 68). Misalnya : ungkapan "Belajarlah yang rajin karena besok ujian”. Jika ungkapan ini disampaikan oleh seorang siswa kepada teman-temannya yang lain maka ungkapan ini termasuk aktus perbincangan sehari-hari (everyday speech act) karena diucapkan atas dasar pengalaman sehari-hari. Berbeda jika yang demikian itu diungkapkan oleh seorang guru maka ini perbincangan yang serius dan termasuk wacana karena diucapkan oleh mereka yang memiliki otoritas dan akan berakibat pada kewajiban belajar bagi siswa tatkala mau ujian dan jika tidak belajar maka akan meninggalkan perasaan bersalah bahkan berdosa.

Dalam kekerasan simbolik, melalui wacana atau bahasa maka pihak dominan berupaya menanamkan suatu habitus tertentu berupa ketaatan pada norma-norma atau tunduk pada ideologi tertentu, mengafirmasi budaya, kebiasaan, gaya hidup tertentu, dan seterusnya. Habitus sendiri sering dipahami sebagai hasil keterampilan yang menjadi tindakan praktis yang tidak selalu harus disadari. Tindakan praktis ini menjadi suatu kemampuan yang kelihatannya alamiah dan berkembang dalam lingkungan sosial tertentu (Haryatmoko, 2010: 14), termasuk dalam keluarga.

Bagi pelaku atau pihak yang dominan, wacana dengan simbol-simbol bahasa yang digunakan sebagai media komunikasi sungguh memegang peranan yang signifikan untuk menggiring, mengarahkan, mempengaruhi, mengontrol sasaran atau korbannya sebagai pihak subdominan. Ini dilakukan dengan beragam cara tetapi yang paling penting menurut Bourdieu bahwa cara pengontrolan dilakukan dengan penciptaan rasa bersalah. Di sini bahasa menjadi sebuah bagian integral dari pertempuran mengontrol pihak lain (Ivan Snook dalam Richard Harker, dkk (ed), 2009:225-226)

Melalui wacana dan atau bahasa, kekerasan simbolis dalam sebuah relasi sosial menyembunyikan kekuatan memaksanya secara sah melalui statemen-statemen yang dituturkan oleh pihak 
dominan yang kemudian dinyatakan dan diberlakukan sebagai statemen universal. Bourdieu mengistilahkannya dengan teknik doxa (Haryatmoko, 2010: 131). Dengan teknik doxa ini maka kekuatan memaksa menjadi tersamarkan, yang tampak malahan sebuah watak relasi sosial yang taken for granted, wajar, dan alamiah, karena kekuatan memaksa disembunyikan dengan cara mengatasnamakan norma-norma tertentu, keilmiahan, bahkan religiusitas.

Kekerasan simbolik seperti ini menjadi laten dan bersifat nirsadar sehingga banyak orang yang tidak menganggap dan tidak mengakui itu sebagai kekerasan karena memang didasarkan atas pelimpahan kepercayaan, loyalitas personal, kesediaan menerima, pemberian, pengakuan, kesalehan, yang semuanya diterima karena sebagai penghormatan etis atau memenuhi kesalehan dan berharap pada keselamatan.

\section{Representasi Kekerasan Simbolik}

Sebagaimana telah dijelaskan di atas bahwa kekerasan simbolik berada di mana-mana dan di ranah apa saja di setiap relasi sosial yang tak seimbang atau tak setara dengan wacana sebagai situsnya, termasuk dalam keluarga. Dalam keluarga, di antaranya, pasti ada hubungan antara orang tua dan anak, kakak dan adik, laki-laki dan perempuan.

Idealnya keluarga menjadi tempat yang nyaman bagi semua penghuninya sehingga bisa menjadi wahana bagi anak-anak untuk mengembangkan kreasinya dan mengaktualisasikan diri seutuhnya. Khusus dalam hubungan antara orang tua dan anak, keluarga sebagai tempat yang memerankan fungsi pendidikan dan pengembangan kepribadian anak. Dalam memerankan fungsi tersebut, orang tua seharusnya mengayomi, melindungi, memberikan rasa aman terhadap anak-anaknya, tidak seharusnya ada sikap kasar, hardikan, ancaman, paksaan, intimidasi, atau hanya sekedar membungkam atau membatasi mereka untuk tidak berpendapat. 
Kenyataan yang terjadi sering terlihat, orang tua yang sedang memerankan dirinya sebagai pendidik dalam keluarga memandang diri lebih superior di hadapan anak-anaknya, baik dari segi pengalaman hidupnya, pengetahuan dan ilmunya, religiusitasnya, dan lain-lain. Perasaan lebih superior ini secara tidak disadari telah mengakibatkan orang tua memosisikan diri sebagai pihak dominan, pula menempatkan diri sebagai penentu kebenaran atas sikap dan perilaku anak-anaknya. Di sinilah menjadi terbuka lebar terjadinya kekerasan dalam hubungan orang tua dan anak; memukul, mencubit, tidak memberi uang saku, tidak diperbolehkan bermain, membentak dan marah, dan seterusnya meskipun itu hanya diungkapkan melalui kata-kata, jika anak tidak menerima dan menuruti orang tua. Biasanya semua itu dilakukan oleh orang tua di bawah alibi mendidik dan mendisiplinkan. Mereka tidak menyadari itu sebuah kekerasan terhadap anak-anak.

Merespon tindakan dan perlakuan dari orang tua seperti tersebut, anak - anak akan merasa sedih, tersinggung, bahkan marah, namun mereka jarang berani untuk membela dirinya atau melawan kehendak, keinginan, dan harapannya. Saat ini yang ada dalam pikiran mereka bahwa melawan orang tua adalah perbuatan durhaka, berani kepada orang tua adalah dosa, bahkan yang terjadi anak-anak juga memaklumi tindakan orang tua atas diri mereka tersebut. Dalam batinnya, seringkali anak menyadari bahwa apa yang dilakukan orang tua adalah baik dan bertujuan untuk kebaikan diri mereka di masa yang akan datang.

Seperti itulah sesungguhnya kekerasan simbolik beroperasi dalam hubungan orang tua dan anak-anak. Baik orang tua sebagai pelaku maupun anak sebagai sasaran atau korbannya, keduanya tidak menyadari jika mereka berada dalam ruang kekerasan. Sebagaimana telah disampaikan di atas bahwa kekerasan simbolik seperti ini menjadi seringkali tidak dianggap, tidak diakui, tidak dirasakan sebagai kekerasan karena memang didasarkan atas pelimpahan kepercayaan, loyalitas personal, kesediaan menerima, 
dan lain-lain yang semuanya diterima karena sebagai penghormatan etis atau berbentuk kesalehan.

Detail representasi lain beroperasinya kekerasan simbolik dalam relasi orang tua dan anak-anak yang perlu diwaspadai dengan adanya wacana-wacana dominasi dalam keluarga, di antaranya :

a. Orang tua yang bersikap tidak akomodatif terhadap pandangan, pendapat, harapan, dan keinginan anak-anaknya. Dia tidak memberikan alternatif pilihan-pilihan lain. Anak dituntut hanya untuk menerima dan mengikuti pendapat, harapan, dan keinginannya. Orang tua mengabaikan pendapat atau pandangan anak sendiri. Bagi orang tua, dia adalah satu-satunya jalan kebenaran dan kebaikan yang harus diikuti. Di sini orang tua telah mencitrakan dirinya sebagai satu-satunya ukuran kebenaran dan kebaikan.

b. Orang tua tak jarang menekan dengan perintah dan larangan yang bertujuan untuk mengarahkan dan mengontrol tindakan anak-anak. Sebagai contoh ada seorang bapak yang memiliki anak belasan tahun yang sedang menghadapi Ujian Nasional (UN) Sekolah Menengah Pertama (SMP), maka dia berkata : "Kamu tidak boleh main futsal semester ini karena kamu akan menghadapi ujian". Demikian pula tatkala ada seorang ibu yang berkata pada anak balitanya yang sedang asyik nonton televisi, "Ayo nak, sudah jam dua, sudah waktunya tidur siang", dan seterusnya.

c. Orang tua kadang-kadang memberikan hadiah, bahkan dengan memberikan kepercayaan kepada anak. Dalam teori-teori pendidikan pemberian hadiah (reward) semacam ini adalah upaya yang sering dilakukan pendidik, baik orang tua maupun guru, untuk memberikan motivasi kepada anak-anak untuk lebih giat lagi belajar, lebih rajin melakukan kebaikan, dan lainlain. Misalnya seorang guru Sekolah Dasar (SD) berkata kepada siswanya :"Yang sudah selesai mengerjakan tugas dari bu guru, bisa dikumpulkan di meja depan dan boleh bermain di luar" 
atau seorang Bapak yang membujuk anak laki-lakinya yang sudah berumur 9 (Sembilan) tahun, "Dek, khitan ya nanti bapak belikan sepeda. Adik anak soleh kan?".

Pada tuturan-tuturan semacam ini justru oleh Bourdieu dinilai bermuatan kekerasan simbolik. Melalui iming-iming hadiah, anak-anak telah dipaksa secara tidak sadar untuk menerima apa yang dikehendaki oleh guru atau orang tuanya. Kekerasan simbolik ini bekerja di bawah sadar sehingga seolah-olah patut bahkan harus untuk diikuti.

Berangkat dari contoh-contoh di atas maka melalui dominasi simbolik, anak-anak menjadi terklasifikasikan menjadi beberapa kelompok. Mereka yang memenuhi tuntutan-tuntutan norma dikelaskan sebagai anak yang saleh, patuh, penurut, baik, dan disiplin. Sedangkan mereka yang melanggar dinilai sebagai anak yang durhaka, bandel, nakal, dan tidak disiplin. Di sinilah, dalam dominasi simbolik inheren kekerasan simbolik.

\section{Dampak Kekerasan Simbolik}

Mendiskusikan kekerasan adalah mendiskusikan kekuatan memaksa pihak lain. Bisa memaksa pihak lain karena faktor-faktor dominasi, hegemoni, dan perasaan superior. Dominasi, hegemoni, dan perasaan superior beragam bentuknya: bisa berupa dominasi fisik dengan merasa lebih kuat, dominasi moral dengan merasa lebih baik, dominasi intelegensi dengan merasa lebih pintar, bahkan agama dengan merasa lebih saleh atau taat.

Apapun bentuknya dominasi mengakibatkan pada pelukaan dan penghancuran dasar kehidupan. Pelukaan atau penghancuran tidak harus ditujukan pada fisik korban atau sasaran yang didominasi. Yang menjadi sasaran bisa kehidupan ekonomi, kehidupan sosial, kondisi psikologi, juga sikap dan cara berpikir korban. Yang terakhir inilah sulit diidentifikasi akibatnya. Kekerasan simbolik yang beroperasi melalui wacana dan atau bahasa dalam komunikasi sehari-hari dan biasanya menjajah perilaku, sikap, dan cara berpikir 
malahan diterima dengan baik oleh korbannya.

Meski sulit diidentifikasi karena dalam realitasnya tidak dinilai dan tidak disadari sebagai kekerasan, akibat atau dampak kekerasan simbolik jauh lebih hebat dibanding kekerasan-kekerasan lain yang sifanya nyata, saumpama kekerasan fisik, karena kekerasan simbolik dalam menguasai dan memaksa korbannya berkait dan berkelindan dengan semua bentuk tindakan, struktur pengetahuan, dan struktur kesadaran individual. Dan akhirnya akan menjebak korbannya dalam menentukan cara bertindak, cara berpikir, dan cara melihat atau memandang sesuatu.

Kekerasan simbolik dalam relasi sosial antara orang tua dan anak dengan penggambaran sebagaimana di atas akan menguasai seluruh sisi kehidupan anak-anak, dari sisi nalar, sikap hidup, kondisi psikhis sampai tindakan nyata. Haryatmoko mengatakan bahwa kekerasan simbolik adalah pintu gerbang menuju ke kekerasan psikologis dan beresiko ke kekerasan fisik (Haryatmoko, 2010: 130).

Kekerasan simbolik yang terjadi karena dominasi simbolik orang tua terhadap anak-anak karena sikap orang tua yang seringkali tidak akomodatif terhadap keinginan anak-anaknya. Orang tua yang semacam ini cenderung bersikap eksklusif. Menurut nalar ini bahwa kebenaran dan kebaikan hanya satu dan ada pada satu pihak. Jika satu pihak benar maka pihak yang lain salah. Sikap eksklusif selalu akan bernalar binair (Raimundo Panikkar dalam Gary E. Kessler, 1999: 532-533).

Sikap eksklusif bernalar binair cenderung melahirkan sikap dan tindakan-tindakan destruktif, seperti: intoleran, tidak demokratis, arogansi, sikap tak mau dikritik, yang semua itu berpotensi melahirkan berbagai benturan, ketegangan, bahkan konflik dan kekerasan psichis maupun fisik.

Satu sisi, kebiasaan orang tua yang seperti tersebut akan menjadi pengalaman yang tak baik bagi anak-anak tatkala nanti mereka akan mengarungi kehidupannya. Mereka akan meniru 
apa yang telah dilakukan orang tua dengan alibi yang sama pula sehingga kebiasaan yang demikian akan diturunkan secara turun temurun, dari generasi ke generasi secara terus menerus. Dalam perspektif ini, teori konvergensi William Stern menyatakan bahwa macam sikap dan perilaku manusia terbentuk secara konvergen, yakni hasil perpaduan antara pembawaan dan lingkungan (nature dan nurture), bahkan Empirisme John Locke mengatakan bahwa macam sikap dan perilaku manusia ditentukan oleh empirinya atau pengalaman-pengalamannya yang diperoleh selama perkembangan individu itu (Abu Ahmadi, 1991: 195-197). Sedangkan sisi yang lain, lagi-lagi anak menjadi korban. Dengan sikap orang tua yang tidak akomodatif terhadap keinginan anak, maka jika anak tidak setuju lalu memprotes dan menolak sikap kesewenang-wenangan orang tua akan sangat dimungkinkan sekali, anak-anak beresiko menerima bentakan, hardikan, ancaman, bahkan pukulan atau kekerasan fisik lainnya dari orang tua.

Demikian pula mencermati kebiasaan orang tua yang seringkali memerintah tanpa mempertimbangkan kemampuan, kondisi fisik dan kejiwaan anak-anak atau orang tua yang suka mengobral larangan dengan ungkapan pokoknya jangan, pokoknya tidak boleh, dan seterusnya. Anak menjadi korbannya.

Selanjutnya kekerasan simbolik yang juga sering dilakukan orang tua atas anak-anaknya dengan memberikan iming-iming hadiah, ini berarti orang tua juga telah melakukan penggiringan agar anak menuju satu ruang tertentu yang dikehendaki orang tua. Anak yang semula merdeka, bebas berkreasi dan berinovasi diarahkan dengan menggunakan bujukan yang menarik agar dia menyetujui dan menerima apa yang dikehendaki orang tua. Sikap yang demikian beresiko memunculkan dampak negatif yang tinggi bagi keberlangsungan kebebasan dan kreativitas pribadi anak. Anak yang seharusnya berhak menentukan dirinya sendiri, diatur dibentuk oleh citra orang tuanya. Resiko terbesar anak akan teraleinasi terhadap dirinya sendiri, dia tak dapat mendefinisikan dirinya sendiri. 


\section{Alternatif solusi}

Persoalan kekerasan simbolik yang seringkali menimpa anak-anak dalam keluarga meski sulit diidentifikasi bukan berarti kekerasan simbolik tidak bisa diminimalisasi. Dalam konteks ini Bourdieu sendiri pernah mengatakan bahwa kekerasan simbolik adalah kekerasan yang sudah tertanam dalam kebiasaan dan sudah berlangsung dalam waktu yang sangat lama sehingga tidak disadari adanya. Karena tak disadari adanya maka kekerasan semacam ini sulit bahkan seakan-akan tidak pernah bisa dihilangkan. Senjata paling ampuh yang mula-mula untuk membuka tabir kekerasan simbolik adalah kesadaran.

Sadar dan mengakui akan adanya kekerasan simbolik, termasuk dalam pendidikan anak-anak oleh orang tua dalam keluarga sebagaimana gambaran di atas harus disosialisasikan terlebih dahulu kepada semua yang ada di sekitar kita. Sosialisasi penyadaran seperti ini menjadi tahap awal untuk memutus rantai kekerasan simbolik secara mutlak demi mewujudkan masa depan anak yang terbebas dari kepungan dominasi.

Setelah itu baru bisa dilakukan beberapa upaya konkret meminimalisasi, mencegah berbagai bentuk kekerasan simbolik yang menimpa anak-anak dalam hubungannya dengan orang tua. Keywordnya adalah pendidikan demokrasi dan mengembangkan sikap paralel. Dengan 2 (dua) keyword tersebut diharapkan pendidikan keluarga yang melibatkan hubungan orang tua dan anakanak bisa menumbuhkan sikap kebersamaan, saling pengertian dan dialog sehingga tercipta saling memahami (mutual understanding).

Orang tua, meski disadari memiliki kelebihan dibanding anak seperti pengalaman, pendidikan, harta atau materi tidaklah boleh semena-mena terhadap anak-anak. Orang tua harus memberi contoh yang baik. Dalam menanamkan pengetauan, moral, religiusitas, dan lain-lain hendaknya lebih mengedepankan prinsip-prinsip pendidikan demokratis, yaitu non-violence, toleransi, dan nondiskriminasi. Prinsip-prinsip tersebut antara lain terekspresikan dalam sikap 
menghormati (respect), memahami (understanding), menerima (acceptance), menghargai perbedaan (appreciating differences), berhutang kepada orang lain (owing the others), dan berempati atau mendalami penderitaan orang lain (absorbing suffer). (Suharso, dkk, 2013: 15)

Di samping melalui pendidikan demokratis, orang tua hendaknya mengembangkan sikap parallel. Sikap parallel sudah benar-benar memandang sama benar dan sama baiknya berbagai pendapat dan kebiasaan orang lain, termasuk anak-anak. Keragaman hanyalah sekedar akibat perbedaan cara pandang terhadap sesuatu (Raimundo Panikkar dalam Gary E. Kessler, 1999: 534).

Hick menganalogikan hal tersebut dengan sekelompok orang buta yang mendeskripsikan tentang gajah, maka mereka akan menceritakannya sesuai dengan pengalaman apa yang dipegangnya. Diletakkan dalam kerangka ini, maka sesungguhnya, adanya keragaman adalah konsekuensi logis dari perbedaan interpretasi karena perbedaan pengalaman. Hick mengatakannya seperti yang dikutip oleh Evans sebagai berikut:

"Hick suggests, however, that differences may be merely apparent. His basic idea is that God "in Himself". Perhaps the apparently conflicting views the various religions have developed about God are like the apparently conflicting descriptions of elephant produced by a group of blind people. The various religions all present images of the devine, each expressing some aspect or range of aspects and yet none by itself fully and exhaustively corresponding to the infinite nature of the ultimate reality. The apparent differences are due to the differing interpretation humans have placed their experience of divine, which are due to the different cultural historical circumstances which have conditioned the experiences" (C. Stephen Evans, 1982:181-182). 
Sikap parallel secara tulus mengembangkan toleransi, watak egaliter, soldaritas antar sesama, saling menghormati, dan menghargai perbedaan, serta keunikan masing-masing, dengan tidak menjastifikasi seseorang akan berada dalam posisi apa dan bagaimana.

\section{Simpulan}

Kekerasan simbolik adalah kekerasan yang beroperasi di bawah ketidaksadaran pelaku maupun korbannya sehingga bersifat nirsadar dan laten sebagai akibat langsung dari adanya perbedaan, pemisahan, ketidaksamaan, ketidaksetaraan atau ketidakseimbangan atau distingsi (distinction) dalam setiap hubungan sosial yang beragam.

Kekerasan simbolik beroperasi melalui wacana dalam relasi orang tua dan anak-anak yang ditandai perilaku orang tua yang selalu menekan anak dengan perintah dan larangan, dan lain-lain yang bertujuan untuk mengarahkan dan mengontrol tindakan anak-anak ke titik tertentu tanpa memberi kelonggaran anak untuk memilih. Kekerasan simbolik dapat berdampak pada ketidakstabilan kejiwaan anak. maka sangat diperlukan tata didik orang tua yang demokratis dan membiasakan sikap parallel. Praktik kekerasan simbolik ini sangat nyata adanya dan perlu diwaspadai karena kekerasan semacam ini seringkali menjadi pemicu munculnya kekerasan yang lain, baik kekerasan psichis, kekerasan fisik, dan lain-lain yang sejatinya harus diretas secara tuntas. 


\section{DAFTAR PUSTAKA}

Ahmadi, Abu. 1991. Psikologi Umum, Semarang: Rineka Cipta. Alam, Rudy Harisyah. 1998. Perspektif Pasca-Modernisme dalam Kajian Keagamaan dalam Tradisi Baru Penelitian Agama Islam: Tinjauan antar Disiplin Ilmu, ed. Mastuhu dan M. Deden Ridwan, Jakarta: Pusjarlit dan Penerbit Nuansa.

E. Deal, William dan Timothy K. Beal. 2004. Theory for Religious Studies, New York, London : Routledge

Evans, C. Stephen. 1982. Philosophy of Religions, England and United State of America : Leicester and Intervarsity Press.

Foucault, Michel . 2002. Archaeology of Knowlegde, terj. AM. Sheridan Smith, London and New York: Routledge Classics.

Haryatmoko.2007. Etika Komunikasi: Manipulasi Media, Kekerasan dan Pornografi, Yogyakarta: Kanisius.

------. 2010. Dominasi Penuh Muslihat Akar Kekerasan dan Diskriminasi, Jakarta: Gramedia Pustaka Utama.

L. Dreyfus, Hubert dan Paul Rabinow. 1982. Beyond Structuralism and Hermeneutic, Chicago: The University of Chicago Press.

Panikkar, Raimundo. 1999. "Four Attitudes" dalam Philosophy of Religion : Toward a Global Perspektif, ed. Gary E. Kessler. Canada, Wardsworth Publishing Company.

Rabinow, Paul (ed.). 1984. The Foucault Reader, London: Penguin Books.

Ricoeur, Paul. 2003. Filsafat Wacana : Membelah Makna dalam Anatomi Bahasa, terj.Masnur Hery, Yogyakarta : Ircisod.

Snook, Ivan. 2009. “Bahasa, Kebenaran, dan Kekuasaan: Ministerium Bourdieu" dalam (Habitus $x$ Modal) + Ranah = Praktik Pengantar Paling Komprehensif Kepada Pemikiran Pierre Bourdieu, ed. Richard Harker, dkk, Yogyakarta : Jalasutra.

Suharno, Samsuri, dan Grendi Hendrastomo, “ Model Peace Building 
Teaching and Learning: Sebuah Intervensi Pencegahan Kekerasan Melalui Pendidikan Formal", dalam http://eprints. uny.ac.id/23718/1/Artikel\%20Jurnal\%20Stranas\%202013. pdf , Diakses 30 September 2016. 
Ulya

Halaman ini bukan sengaja untuk dikosongkan 